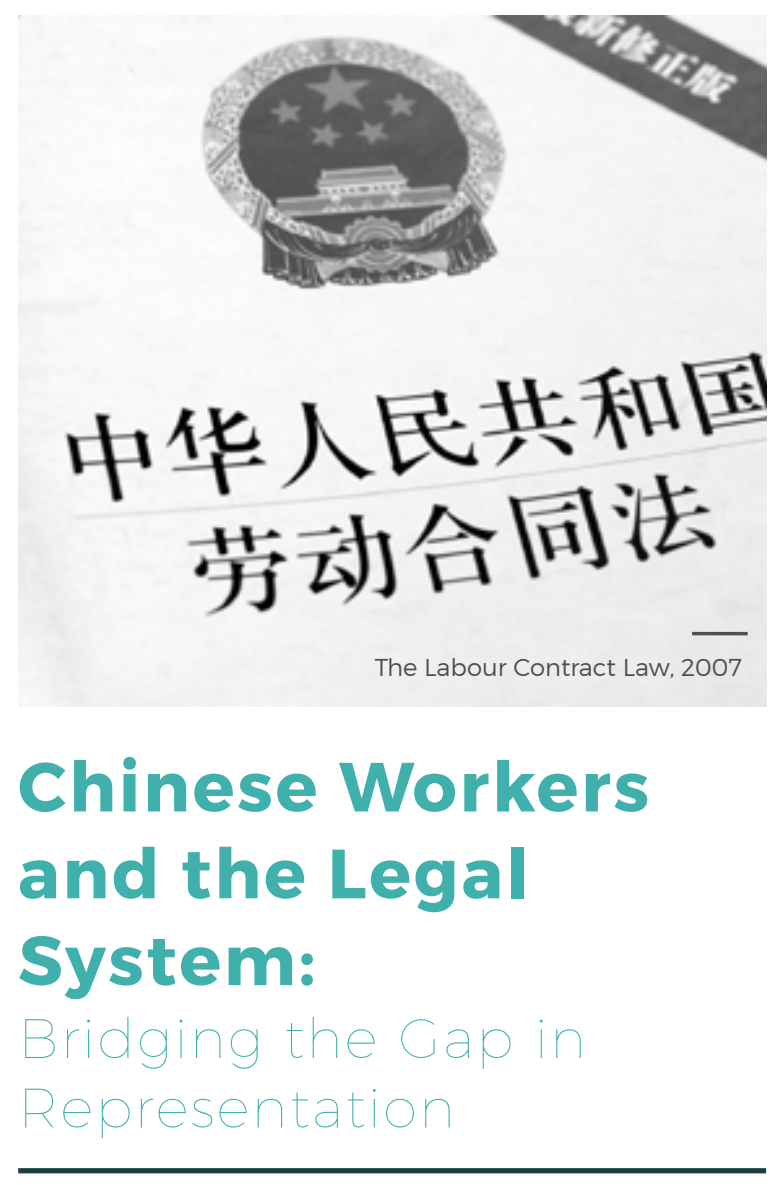

\section{Aaron Halegua}

A decade ago, the Chinese authorities adopted a set of new laws to grant increased legal protections to workers and easier access to the legal system to enforce their rights through litigation. Since then, Chinese workers have increasingly turned to labour arbitration and courts in the hope of resolving their grievances. But how do they fare in this process? And are they able to find legal representation?
In 2007, the Chinese authorities issued the Labour Contract Law to grant new legal protections to workers and the Labour Dispute Mediation and Arbitration Law to make it easier for them to enforce their rights through litigation. In the decade that followed, Chinese workers have increasingly turned to labour arbitration and courts in the hope of resolving their grievances. But how do they fare in this process? Are they able to find legal representation? In China, as elsewhere, a significant 'representation gap' exists between workers' legal needs and the available legal services.

A new report that I authored, Who Will Represent China's Workers? Lawyers, Legal Aid, and the Enforcement of Labour Rights, takes an in-depth look at the landscape of enforcing worker rights in China, with a particular focus on trends in labour rights litigation and the availability of legal representation. The report draws on over one hundred interviews, observations from litigation proceedings, and an extensive review of published and unpublished written materials. The executive summary lists seven 'key findings', including that the number and diversity of labour disputes is rising; mediation has become the predominant means of resolving labour disputes; workers are often unsuccessful in litigation; and represented workers achieve better outcomes in litigation.

Finding competent legal representation to assist in the litigation process remains a challenge for workers, however. Due to economic and political considerations, private lawyers and law firms are reluctant to represent workers. 'Barefoot lawyers' have been essentially banned and labour NGOs are significantly constrained in the current political environment. More workers are represented each year by the government-sponsored legal aid system, which pays private lawyers a set stipend to handle cases regardless of the outcome. But many workers are still turned away and those who receive a lawyer are 
often dissatisfied with the quality of the representation.

In addition to describing the above trends, the report takes an initial step towards quantifying the representation gap and other aspects of labour litigation. In collaboration with the Chinese data analytics company Legal Miner, over thirty thousand publicly available court decisions were collected and then analysed to determine how many workers have a legal representative, the identity of these representatives (licensed lawyers versus other providers), and the average length of the court proceedings. A significant number of workers, roughly forty percent, had no legal representation in court. However, plaintiffs who make it all the way to court are only the tip of the iceberg in terms of workers who need legal assistance but are unable to obtain it.

In light of this representation gap, the penultimate section of the report sets forth eight practical strategies to narrow the chasm and improve the enforcement of labour rights. Some proposals seek to decrease the 'demand' for legal services by reducing labour violations in the first place. Others are designed to increase the 'supply' of quality legal representation for workers. In the remainder of this article, I discuss three of these strategies that have received less attention: (1) strengthening anti-retaliation measures; (2) imposing criminal sanctions and establishing personal liability for employers; and (3) encouraging the growth of a plaintiffs' bar.

The first two strategies address the 'demand' side of the representation gap. One crucial reason for the prevalence of noncompliance with labour standards, and thus the large number of aggrieved workers, is the lack of adequate deterrents for employers. The labour inspectorate in China, which enforces labour laws, employs just one inspector for every thirty thousand workers. For the most part, investigations only occur in response to a worker filing a complaint. Furthermore, even when violations are detected, a fine against the employer is only imposed in 3.4 percent of cases. Accordingly, measures are needed to both encourage workers to come forward with violations and raise the penalties for employers who are not in compliance-which the first two strategies do. The third strategygrowing a robust plaintiffs' bar-most directly addresses the 'supply' side of the representation gap, but a heightened threat of litigation against employers could also lead to increased compliance.

\section{Anti-Retaliation Measures}

Employer retaliation against workers who complain about unfair or illegal working conditions is commonplace-not only in China, but also other countries. In the United States, for instance, over forty-four percent of the nearly ninety thousand charges filed with the federal anti-discrimination agency in 2015 contained an allegation of retaliation, making it the most frequent complaint. This agency even made combating retaliation a 'national priority'. As for China, a survey of Foxconn employees revealed that over forty-seven percent of workers experienced retaliation after raising a complaint. Eighty percent of Guangzhou workers feared that suing their employer would result in their termination. If workers are too afraid to complain about violations, employers will not be held accountable. With nothing to fear, employers will continue violating the law.

The Chinese government may consider adopting anti-retaliation protections for workers who protest employer violations of discrimination, workplace safety, and other labour laws. The concept of an anti-retaliation measure is not foreign to China. Indeed, similar protections already exist for trade union officers, 
workers who complain to the labour inspectorate, and certain witnesses. The best model may be the fairly robust antiretaliation provisions to protect whistleblowers that China promulgated in 2016, which includes a broad list of actions that constitute retaliation.

Labour advocates might propose that any amendments to the Labour Contract Law, which is rumoured to be revised in the near future, include an antiretaliation provision. This would provide an opportunity not only to explicitly prohibit retaliation, but also establish procedures for handling complaints and set meaningful penalties against violators. In light of speculation that the other amendments will be designed to increase the flexibility of employers, and may even broaden the grounds upon which employees can be terminated, it is particularly important to make explicit that workers cannot be fired for challenging illegal conditions in the workplace.

\section{Criminal Prosecutions and Personal Liability}

Another strategy to deter employer noncompliance is to hold them personally accountable for any violations, including through criminal prosecutions. In 2011, China amended its Criminal Law to establish criminal penaltiesincluding fines and imprisonment-for the malicious non-payment of wages. Where an employer has been ordered to pay a 'comparatively large sum' of wages, but instead chooses to transfer assets or otherwise evades payment, he may be held criminally liable. The Chinese government has already demonstrated some willingness to undertake these prosecutions: 753 cases were prosecuted in 2014 and nearly one thousand and two hundred in 2015, an increase of fifty-eight percent. But while Shenzhen alone brought ninety-three cases in
2014, Beijing did not prosecute its first case until 2013 and is reported to only undertake about forty per year.

Labour advocates should engage local governments to increase both the number of criminal prosecutions and their impact. Chinese officials complain that the most significant obstacle to achieving more prosecutions is the poor evidence that workers bring to the government. Accordingly, one potential area for cooperation is for the government to educate lawyers and labour NGOs about the types of cases and evidence they seek, and for these advocates to then identify cases that are ripe for prosecution-thus resulting in more prosecutions. Another aspect of this type of cooperation would be for labour advocates to assist in publicising the prosecutions that occur. If employers are aware that these prosecutions are happening, and with increasing frequency, they are more likely to be deterred from committing similar violations.

An additional prong of this deterrence strategy is to create civil liability for individual employers. At present, an individual does not have the capacity to be an 'employer' under Chinese labour law. Therefore, a judgment for unpaid wages can only be issued against the corporate entity that employed a worker and may only be enforced against the assets of the corporation. The individual employer has little to fear. Labour law scholar Xie Zengyi writes that this lack of individual accountability has a lot to do with the poor implementation of labour law in China. Therefore, labour advocates should propose establishing such individual liability so that judgments can be enforced against the personal assets of the individual employer.

\section{Plaintiffs' Bar}

Given their current reluctance, the emergence of a bar of Chinese lawyers 
committed to representing workers would significantly help to narrow the representation gap and improve the enforcement of labour rights. If the compensation structure were properly aligned, attorneys could become entrepreneurial and zealous advocates for workers. The report recommends reforms in three areas-contingency fee arrangements, aggregate litigation, and fee-shifting provisions-that would help create such incentives.

Contingency fee arrangements-by which the lawyer only collects fees if the client recovers money-are generally banned in labour cases. Workers are therefore required to pay legal fees upfront, which many cannot afford. Permitting contingency fee arrangements would allow lawyers to represent workers with strong cases, regardless of whether they could afford to pay. Moreover, as contingency fees are often calculated based on a percentage of the compensation awarded to the worker, they may allow attorneys to earn more money in cases where there are sizeable recoveries.

Bringing collective or class litigation is difficult in China. But aggregating small, individual claims can be an effective way to make litigating those cases economically viable for a lawyer. For instance, a China Labour Watch report discovered that seventy thousand workers at Pegatron attended a fifteen-minute meeting each day for which they were not compensated. Litigating the claim of one worker may not be worth a lawyer's time; but if one lawsuit could be brought on behalf of all workers, who are collectively owed over eleven million US dollars, the case would be quite attractive. Therefore, labour advocates should promote the adoption of measures to facilitate collective and class labour cases.

A final reform to help encourage the growth of a plaintiffs' bar is a properly structured fee-shifting scheme. Shenzhen already permits workers to be awarded legal fees when they prevail in labour cases, but several aspects of that system limit its utility and impact. Due to restrictions on contingency fees, plaintiffs must still front the legal fees before a court can require the employer to reimburse those fees. In other countries, fee-shifting schemes can deter employers from dragging out litigation because the amount of the fees is calculated based on the number of hours worked by the plaintiff's counsel. In Shenzhen, the legal fee is tied to how much the worker actually paid his lawyer and is capped at five thousand yuan per procedurehardly enough to deter most employers. But if this system were modified, it has great potential to help narrow the representation gap.

\section{Conclusion}

As the Chinese government considers rolling back some of the labour protections previously granted to workers in the Labour Contract Law, it becomes even more important to ensure that whatever rights still exist are adequately enforced. For a more comprehensive discussion of the landscape of labour rights enforcement in China and other proposed strategies for narrowing the representation gap, readers are encouraged to access the full report.

\section{Aaron Halegua}

Aaron Halegua is a practicing lawyer, consultant, and research fellow at the NYU School of Law. He has published a variety of book chapters, journal articles, and op-eds on labour and employment law issues in the United States and China. More information on his work is available on his website: http://www.aaronhalegua.com. 